\title{
U-Pb geochronology of the Santa Cruz Formation (early Miocene) at the Río Bote and Río Santa Cruz (southernmost Patagonia, Argentina): implications for the correlation of fossil vertebrate localities
}

José I. Cuitiño ${ }^{1 *}$, Juan Carlos Fernicola ${ }^{2,3}$, Matthew J. Kohn ${ }^{4}$, Robin Trayler ${ }^{4}$, Maximiliano Naipauer $^{5}$; M. Susana Bargo ${ }^{6,7}$, Richard F. Kay ${ }^{8}$, Sergio F. Vizcaíno ${ }^{6,9}$

1-IPGP, CENPAT-CONICET. Boulevard Almirante Brown 2915, Puerto Madryn (U9120ACD), Chubut, Argentina.jcuitino@cenpat-conicet.gob.ar

2- Sección Paleontología de Vertebrados, Museo Argentino de Ciencias Naturales "Bernardino Rivadavia"-CONICET. Av. Ángel Gallardo 470, 1405DJR Ciudad Autónoma de Buenos Aires, Argentina,jctano@yahoo.com

3-Departamento de Ciencias Básicas, Universidad Nacional de Luján, Ruta 5 y Avenida Constitución, 6700 Luján, Buenos Aires, Argentina.

4-Department of Geosciences, Boise State University, 1910 University Drive, Boise, Idaho, USA, mattkohn@boisestate.edu; robintrayler@u.boisestate.edu

5-Instituto de Estudios Andinos (IDEAN)-CONICET, Intendente Guiraldes 2160, Ciudad Autónoma de Buenos Aires, Argentina, maxinaipauer@gl.fcen.uba.ar

6- División Paleontología Vertebrados, Museo de La Plata, Unidades de Investigación Anexo Museo, 60 y 122, La Plata, Argentina, vizcaino@fcnym.unlp.edu.ar

7- CIC, msbargo@fcnym.unlp.edu.ar

8- Department of Evolutionary Anthropology and Division of Earth and Ocean Sciences, Box 90383,

Duke University, Durham, NC 27708, USA. richard.kay@duke.edu

9- CONICET

*Corresponding author

\begin{abstract}
The early Miocene Santa Cruz Formation (SCF) in southern Patagonia hosts the Santacrucian South American Land Mammal Age (SALMA), whose age is known mainly from exposures along the Atlantic coast. Zircon U-Pb ages were obtained from intercalated tuffs from four inland sections of the SCF: $17.36 \pm 0.63$ Ma for the westernmost Río Bote locality, and 17.04 \pm $0.55 \mathrm{Ma}$ to $16.32 \pm 0.62 \mathrm{Ma}$ for central Río Santa Cruz localities. All ages agree with the bounding age of underlying marine units and with equivalent strata in coastal exposures. New ages and available sedimentation rates imply time spans for each section of $\sim 18.2$ to $17.36 \mathrm{Ma}$ for Río Bote and 17.45 to 15.63 Ma for central Río Santa Cruz (Burdigalian). These estimates support the view that deposition of the SCF began at western localities $\sim 1$ Ma earlier than at eastern localities, and that the central Río Santa Cruz localities expose the youngest SCF in
\end{abstract}


southern Santa Cruz Province. Associated vertebrate faunas are consistent with our geochronologic synthesis, showing older (Notohippidian) taxa in western localities and younger (Santacrucian) taxa in central localities. The Notohippidian fauna (19.0 to 18.0 Ma) of the western localities is synchronous with Pinturan faunas (19.0 to 18.0 Ma), but older than Santacrucian faunas of the Río Santa Cruz (17.2 to 15.6 Ma) and coastal localities (18.0 to 16.2 Ma). The Santacrucian faunas of the central Río Santa Cruz localities temporally overlap Colloncuran (15.7 Ma), Friasian (16.5 Ma), and eastern Santacrucian faunas.

Keywords: Santacrucian, Notohippidian, chronostratigraphy, fossil mammals 


\section{Introduction}

The early Miocene Santa Cruz Formation (SCF) is a terrestrial sedimentary unit, widely distributed in the Austral (or Magallanes) Basin in southern Patagonia (Fig. 1). It is one of the richest Cenozoic vertebrate fossil units of South America upon which was based the Santacrucian South American Land Mammal Age (SALMA) (e.g. Simpson 1940; Vizcaíno et al. 2012, and references therein). The SCF crops out in a large area within Santa Cruz Province (Fig. 1B), including the northwest region of Lago Posadas and Lago Belgrano, the central and southwest regions of Lago Cardiel and Lago Argentino and the southeastern region along the Atlantic coast between Monte León and the Río Gallegos estuary (Fig. 1b). The first geologic section and fossils of the SCF were described by Sulivan in 1845 from the cliffs of the Río Gallegos (Brinkman, 2003). The formation was intensively prospected along the Río Santa Cruz and Río Bote in 1877 and 1887 by F.P. Moreno and C. Ameghino, respectively (Fig. 1). Another important expedition lead by S. Pozzi and C. Onelli from the Museo de La Plata was launched to the same area in $1888-1889$, but its results were not formally published (Brinkman and Vizcaíno, 2014). The SCF beds along the Río Santa Cruz served as the basis for the definition of the Santacrucian Stage sensu F. Ameghino (1889). Attention to these sections rapidly declined after these early field expeditions due to the discovery of exceptionally fossiliferous Atlantic coastal localities by C. Ameghino in 1890.

Certainly, in the southeastern region of the province, along the Atlantic coastal zone between the Río Santa Cruz and Río Gallegos, the most extensive and continuous outcrops of the SCF are superbly exposed. Consequently, most of the paleontologic, stratigraphic and geochronologic research has focused on the coast (e.g. Vizcaíno et al., 2012 and references therein). Despite further sporadic visits by a few geologists and paleontologists during the $20^{\text {th }}$ and early $21^{\text {st }}$ centuries, the Río Santa Cruz and Río Bote localities originally visited by Moreno remained virtually forgotten (Marshall, 1976). Recently Fernicola et al. (2014) revisited, relocated and described these localities, reinitiating intensive geologic and paleontologic studies.

Radiometric ages of the SCF were first provided by Marshall et al. (1986) and Fleagle et al. (1995) for coastal (eastern) and Andean (western) localities. Blisniuk et al. (2005) published results for the SCF for northwestern Andean region, and Perkins et al. (2012) and Fleagle et al. (2012) more precisely constrained the ages of numerous costal and Andean SCF localities by means of ${ }^{39} \mathrm{Ar} /{ }^{40} \mathrm{Ar}$ and provided a regional framework for correlation based on tephrochronology. No radiometric ages or tephrochronological 
constraint for the SCF were available along the Río Bote and Río Santa Cruz localities, however. To redress this deficiency, we provide four new laser ablation-inductively coupled plasma-mass spectrometer (LA-ICP-MS) U-Pb zircon ages from tuff beds of the SCF exposed at these localities. These ages allow us to integrate these localities within the regional chronostratigraphy available for the SCF across southern Patagonia. We also provide a preliminary account of the fossil taxa collected at each locality and discuss the significance of faunal differences in relation to age and geographic distribution.

Figure 1. Location maps. A) Regional location of the study area. PI: Pilcaniyeu Ignimbrite; RC: Río Cisnes; GB: Gran Barranca. B) The distribution of the SCF and equivalent terrestrial Miocene units in the Santa Cruz Province is indicated (yellow). LPo: Lago Posadas; PSN: Portezuelo Sumich Norte; MBe: Meseta Belgrano; LCa: Lago Cardiel; RCh: Río Chalía; LAr: Lago Argentino; SBa: Sierra Baguales; RSC: Río Santa Cruz; MLNP: Monte León National Park; RCo: Río Coyle; RGa: Río Gallegos. C) Santacrucian localities in southern Patagonia mentioned in this work. Red stars indicate study localities: RB: Río Bote; YH: Yaten Huageno; SBB: Segundas Barrancas Blancas; BB: Primeras Barrancas Blancas. The green dashed line indicates part of the trace of the cross-section of Fig. 8.

\section{Geologic setting and study area}

The SCF is part of the infill of the Austral (or Magallanes) Basin, which is located in far-southern South America (Fig. 1). This basin was formed on the foreland side of the Southern Patagonian Andes. Two major phases of basin development are recognized (Biddle et al., 1986): a rift stage during the Early Cretaceous and a foreland stage during the Late Cretaceous and Cenozoic. Flexural subsidence during the foreland stage was related to the development of a fold- and -thrust belt to the west. To the northeast, the basin is limited by a major crustal block known as the Deseado Massif and to the west by the Andean fold-and-thrust belt (Ramos, 1989), which controlled and limited the development of depositional areas, including those for the SCF. During Miocene times, a major phase of uplift of the Andes created the accommodation space in the foreland needed for the accumulation and preservation of thick and widespread terrestrial and marine deposits (Blisniuk et al., 2005; Fosdick et al., 2013; Cuitiño et al., 2015). The marine deposits of this period are informally known as "Patagoniense" transgression, and include the Monte León (Bertels, 1970, 1980), the Estancia 25 de Mayo (Cuitiño 
and Scasso, 2010) and the El Chacay (Chiesa and Camacho, 1995) formations. The terrestrial Miocene deposits are known as the Santa Cruz Formation (Ameghino 1989; Furque and Camacho, 1972), Pinturas Formation (Bown and Larriestra, 1990) and Río Zeballos Group (Ugarte 1956; Giacosa and Franchi, 2001).

The outcrops of the SCF studied here are located in two different structural domains: 1) the Río Bote outcrops form part of a distal frontal monocline associated with the Southern Patagonian fold-and-thrust belt (Ghiglione et al., 2009) and show a gentle (less than $5^{\circ}$ ) dip to the east; 2) the eastern outcrops along the Río Santa Cruz form part of extra-Andean Patagonia and are nearly horizontal (Fig. 2).

The western fossiliferous locality lies in the eastern margin of the Río Bote valley, a tributary of the Río Santa Cruz located to the west of the study area (Fig. 2). At this location, the marine early Miocene Estancia 25 de Mayo Formation underlies the SCF (Cuitiño and Scasso, 2010; Cuitiño et al., 2012). The remaining three studied outcrops are along the southern margin of the Río Santa Cruz (Figs. 1c and 2). This river drains to the east along a wide E-W incised valley that begins at Lago Argentino to the west and empties into the Atlantic Ocean to the east. This glacial-fluvial valley cuts deeply into the late Cenozoic sedimentary cover of the Austral Basin. The lowest exposed unit is the early Miocene Monte León Formation (MLF) (Bertels, 1970; Parras et al., 2012), the outcrops of which are visible to the east, near the valley floor (Fig. 2). Overlying the MLF is the SCF, which is the best-exposed unit especially along the southern margin of the valley. Our observations and sample collections were made at three locations along the river. The four localities studied here correspond to those previously located and described by Fernicola et al. (2014) who revised the history of the pioneering paleontological studies performed by Carlos Ameghino (C. Ameghino, 1890) in these sites.

Figure 2. Geologic map of the study area. Red arrows indicate the localities studied.

\subsection{The Santa Cruz Formation in southern Santa Cruz Province}

Stratigraphic, sedimentological and compositional data published for the SCF focuses on the coastal localities of southeast Santa Cruz Province, especially between the Río Coyle and the Río Gallegos estuaries (Fig. 1c). Ameghino (1906) and Feruglio (1949) described the general stratigraphic features of this region and pointed out a gentle tilt of the unit to the south. Feruglio (1949) described fine-grained tuffs, 
mudstones and intercalated dark sandstone levels for his Santacrucense (=SCF) beds in this region. At two coastal localities north of Río Coyle, Bown and Fleagle (1993) described the SCF sedimentology, highlighting the elevated proportion of pyroclastic material and the abundant pedogenetic modifications of the sediments. Tauber (1994) provided the most complete and detailed description for some sections to the south of

Río Coyle. Based on lithological differences, he divided the SCF into two members: a lower member (later called the Estancia La Costa Member, Tauber, 1997) dominated by fine-grained pyroclastic and epiclastic beds; and an upper member (later called the Estancia La Angelina Member, Tauber, 1997), which is dominated by epiclastic mudstones and sandstones. Recently, Matheos and Raigemborn (2012) and Raigemborn et al. (2015) performed detailed sedimentologic analysis for the lower part of the SCF and its transition to the underlying MLF at the coastal localities south and north of Río Coyle, respectively. They interpreted the lower SCF beds as a low-energy, floodplaindominated fluvial system affected by pyroclastic input with poorly developed paleosols. Kay et al. (2012a) integrated sedimentologic and paleontologic data for coastal localities and concluded that climate during the deposition of SCF was warm temperate and exhibited high precipitation seasonality, with cool wet winters and warm dry summers.

Away from the coastal localities, the SCF is poorly known. Early general descriptions where provided by the Ameghino brothers (C. Ameghino, 1890; F. Ameghino, 1889) who included descriptions for the Río Santa Cruz valley (Fernicola et al., 2014). Feruglio $(1938,1949)$ compiled a large number of detailed stratigraphic observations in the Austral Basin as a whole excepting only the Río Santa Cruz valley. Feruglio stressed the transitional relations between the underlying marine "Patagoniense" beds and his Santacruciano (= SCF) beds. In the Lago Argentino region, Furque and Camacho (1972) and Furque (1973) described a generalized section of the SCF, measuring a total thickness of about 500 meters.

\section{Previous age determinations of the Santa Cruz Formation}

$\mathrm{K}$-Ar radiometric ages from tuffs of the SCF were first provided by Marshall et al. (1986) who, with the aid of magnetostratigraphic methods, calibrated the age of the unit for two coastal localities (Monte León and Rincón del Buque) and one western locality near Lago Argentino (Estancia La Laurita = Karaiken) $($ Fig. 1c), and proposed a range of ages from 17.6 to 16.0 Ma for the unit as a whole. Later, Bown and Fleagle (1993) and Fleagle et al. (1995) provided ${ }^{40} \mathrm{Ar} /{ }^{39} \mathrm{Ar}$ ages of 16.59 to $16.18 \mathrm{Ma}$ from plagioclase 
and biotite separated from tuffs preserved in the lower beds of the SCF at the coastal localities of Monte León and Monte Observación (now Cerro Observatorio, Fleagle et al., 2012), and reported an age of 19.33 Ma for the top of the underlying MLF. Based on these results, these authors proposed an erosional disconformity between the marine and continental deposits of the SCF and MLF, respectively, which represented a prolonged hiatus of nearly $3 \mathrm{Ma}$. Blisniuk et al. (2005) provided ${ }^{40} \mathrm{Ar} /{ }^{39} \mathrm{Ar}$ ages from tuffs of the SCF at Meseta Belgrano, about $400 \mathrm{~km}$ north of our study area. These ages bracket the SCF at this region between 22 and $14 \mathrm{Ma}$. The oldest age provided by Blisniuk et al. (2005) was questioned by Perkins et al. (2012) who, based on a sediment accumulation curve, suggested the SCF should not be older than 19 Ma at Meseta Belgrano. Recently, Cuitiño et al. (2015) provided eight ${ }^{87} \mathrm{Sr} /{ }^{86} \mathrm{Sr}$ ages for the underlying marine Patagoniense deposits at Meseta Belgrano, indicating that the lower beds of the SCF are not older than $\sim 18 \mathrm{Ma}$. The age of the SCF in southeastern Santa Cruz Province is constrained by ${ }^{87} \mathrm{Sr} /{ }^{86} \mathrm{Sr}$ data of the underlying marine MLF which span an age range between 22.12 and $18 \mathrm{Ma}$ (Parras et al., 2008, 2012). The younger age ( 18 Ma) represents levels located about 60 meters below the transition of the Monte León and Santa Cruz formations, implying that the SCF must be younger than $\sim 18 \mathrm{Ma}$. Perkins et al. (2012) dated the lowermost part of the SCF in Monte León at 17.71 Ma, which suggests no hiatus between deposition of the MLF and SCF. Sedimentological evidence shows a continuous transition between the sedimentary units (Feruglio, 1938;

Raigemborn et al., 2015). For the Lago Argentino region, Cuitiño et al. (2012) provided a combination of ${ }^{87} \mathrm{Sr} /{ }^{86} \mathrm{Sr}$ ages from calcitic oyster shells and U-Pb ages from tuff beds for the underlying Estancia 25 de Mayo Formation, placing the base of the SCF at 18.85 Ma at Arroyo Los Perros (Fig. 1c). An older age for the lower part of the SCF in southwest Patagonia compared to coastal localities is also supported by U-Pb SHRIMP ages from detrital zircons in Sierra Baguales, Chile (Bostelmann et al., 2013).

Collectively, these ages demonstrate that the transition from the underlying marine beds to the SCF from western to eastern localities is diachronous by about $1 \mathrm{Ma}$. Perkins et al. (2012) and Fleagle et al. (2012) updated the age of the SCF by means of step-heating ${ }^{40} \mathrm{Ar} /{ }^{39} \mathrm{Ar}$ ages, and correlated numerous coastal and western localities using chemical tephrostratigraphy. These authors concluded that the ages of the SCF span the interval $\sim 18$ to $16 \mathrm{Ma}$ for coastal localities. An individual ${ }^{40} \mathrm{Ar} /{ }^{39} \mathrm{Ar}$ age of $16.5 \mathrm{Ma}$ provided by Tejedor et al. (2006) for the Río Gallegos estuary zone is in agreement with the chronostratigraphic framework provided by Perkins et al. (2012). 
In summary, a well-calibrated chronostratigraphic scheme is available for the coastal localities of the SCF. However, geochronologic data for other inland localities are scarce. The study area lacks published radiometric age control and its stratigraphic, sedimentologic and paleontologic features are poorly known outside of a general description of the geology of the Río Santa Cruz valley (Fernicola et al., 2014).

\section{Materials and Methods}

The Río Bote and Río Santa Cruz sections are measured and described. The elevation above sea level of base, top and tuff beds for each section was measured with conventional GPS devices. The localities are labeled after Fernicola et al. (2014) which from west to east are (Figs. 1c and 2): Río Bote, located in the southern margin of the Río Bote valley in the Estancia María Elisa; and three localities along the southern margin of the Río Santa Cruz: Yaten Huageno, located at Estancia El Refugio; Segundas Barrancas Blancas, an outcrop that includes parts of the Estancia Cordón Alto, Estancia El Tordillo and Estancia Rincón Grande; and Barrancas Blancas, the easternmost studied outcrop located in Estancia Aguada Grande and Estancia Santa Lucía. Other localities with SCF exposures in the Santa Cruz Province are labeled following Vizcaíno et al. (2012) (Fig. 1c).

Tuff sample selection in the field was based on stratigraphic position, grain-size and degree of reworking by posteruptive sedimentary processes. Twelve tuff samples distributed among all localities were collected at different stratigraphic levels for geochronologic analysis. Petrographic examination of each sample in the laboratory characterized grain-size, mineralogy, and possible epiclastic contamination. Tuff grainsize categories follow the proposal of White and Houghton (2006). Based on petrographic indicators of reworking (e.g. abundance of non-volcanic lithic particles), stratigraphic position, and geographic position, six of the twelve samples were chosen for further preparation for dating. This process involved crushing, sieving and subsequent heavy mineral concentration by hydraulic methods. A Frantz Magnetic Separator was used to remove the abundant magnetite, hornblende and pyroxene grains. Finally, the zircon grains were hand-picked from the heavy concentrate under a binocular microscope. Based on zircon quantity and quality (e.g. lack of rounding; longprismatic habit; large size) four samples were chosen for final $\mathrm{U}-\mathrm{Pb}$ dating. These samples, from west to east, are (Fig. 2): RSC-27 from Río Bote (S50²1'52.9”; W71 ${ }^{\circ} 50$ '18.9”), RSC-20 from Yaten Huageno (S50¹5'40.7”; W71 03 '48.8”); CECA-2 
from Estancia El Tordillo in Segundas Barrancas Blancas (S50 16'43”; W70 15' 9.9”) and RSC-7 from Estancia Aguada Grande in Barrancas Blancas (S5009'56.1”; W694'09.6").

Age calculation for base, top and/or any specific interval of each studied section of the SCF is based on the average sedimentation rate of $\sim 150 \mathrm{~m} / \mathrm{Ma}$ obtained for several localities such as Cabo Buen Tiempo, Puesto Estancia La Costa, Cerro Observatorio, Monte León, Río Chalía and Karaiken (Perkins et al., 2012), and at Lago Posadas (Blisniuk et al., 2005) (Fig 1). Ages derived from sedimentation rate calculation are preceded by the symbol “ ".

\subsection{U-Pb geochronology methods}

Prior to analysis, zircon grains were annealed at $900^{\circ} \mathrm{C}$ for 60 hours in a muffle furnace, then mounted in epoxy and polished until their centers were exposed. Cathodoluminescence (CL) images were obtained with a JEOL JSM-1300 scanning electron microscope and Gatan MiniCL. Analyses were performed using a Thermo Electron X-Series II quadrupole ICPMS and New Wave Research UP-213 Nd:YAG UV $(213 \mathrm{~nm})$ laser ablation system, housed in the BioTrace laboratory at Boise State University. In-house analytical protocols, standard materials, and data reduction software were used to acquire and calibrate U-Pb dates and a suite of high field strength elements (HFSE) and rare earth elements (REE). Zircon was ablated with 25-30 $\mu \mathrm{m}$ diameter laser spots using fluence and pulse rates of $\sim 5 \mathrm{~J} / \mathrm{cm}^{2}$ and $10 \mathrm{~Hz}$, respectively, during a 45 second analysis (15 sec gas blank, $30 \mathrm{sec}$ ablation) that excavated a pit 25 $\mu \mathrm{m}$ deep. Ablated material was carried by a $1.2 \mathrm{~L} / \mathrm{min}$ He gas stream to the nebulizer flow of the plasma. Dwell times were $5 \mathrm{~ms}$ for $\mathrm{Si}$ and $\mathrm{Zr}, 200 \mathrm{~ms}$ for ${ }^{49} \mathrm{Ti}$ and ${ }^{207} \mathrm{~Pb}, 80$ ms for ${ }^{206} \mathrm{~Pb}, 40 \mathrm{~ms}$ for ${ }^{202} \mathrm{Hg},{ }^{204} \mathrm{~Pb},{ }^{208} \mathrm{~Pb},{ }^{232} \mathrm{Th}$, and ${ }^{238} \mathrm{U}$ and $10 \mathrm{~ms}$ for all other HFSE and REE. Background count rates for each analyte were obtained prior to each spot analysis and subtracted from raw count rates. Ablations pits that appeared to have intersected glass or mineral inclusions were identified by time-resolved data that showed large fluctuations in $\mathrm{Ti}$ or $\mathrm{P}$. U-Pb dates from these analyses were considered valid if the time-resolved $\mathrm{U}-\mathrm{Pb}$ ratios appeared to have been unaffected by the inclusions. Analyses that appeared contaminated by common $\mathrm{Pb}$ were rejected based on an intensity of mass 204 above baseline.

For U-Pb dates, instrumental fractionation of the background-subtracted ratios was corrected and dates were calibrated with respect to interspersed measurements of the 
Plešovice zircon standard (Sláma et al., 2008). Two analyses of Plešovice were collected after every 10 analyses of unknown zircon; a polynomial fit to the standard analyses yields each sample-specific fractionation factor. Signals at mass 204 were indistinguishable from zero following subtraction of mercury backgrounds measured during the gas blank ( $<1000 \mathrm{cps}{ }^{202} \mathrm{Hg}$ ), and thus dates are reported without common $\mathrm{Pb}$ correction. Radiogenic isotope ratio and age error propagation for all analyses includes uncertainty contributions from counting statistics and background subtraction. For groups of analyses that were collectively interpreted from a weighted mean date (i.e., igneous zircon analyses), a weighted mean date was first calculated using Isoplot 3.0 (Ludwig, 2003) using errors on individual dates that do not include a standard calibration uncertainty. A standard calibration uncertainty was then propagated independently into the error on the weighted mean date. This calibration uncertainty includes the standard deviation of the time-varying $\mathrm{U} / \mathrm{Pb}$ fractionation factor and the standard error of the mean of the time-invariant, smaller ${ }^{207} \mathrm{~Pb} /{ }^{206} \mathrm{~Pb}$ fractionation factor. Data were collected in two experiments in November 2013. Standard calibration uncertainties for ${ }^{206} \mathrm{~Pb} /{ }^{238} \mathrm{U}$ dates were $3.23 \%$ and $2.66 \%(2 \sigma)$, respectively. Age interpretations are based on ${ }^{206} \mathrm{~Pb} /{ }^{238} \mathrm{U}$ dates. Errors on the dates from individual analyses are given at $2 \sigma$, as are the errors on the weighted mean dates.

A zircon secondary reference material was treated as an unknown to assess accuracy, interspersed as groups of two analyses for every 20 unknown analyses. Weighted mean dates were calculated using Isoplot 3.0 (Ludwig, 2003) from errors on individual dates that do not include the standard calibration uncertainties. However, errors on weighted mean dates include the standard calibration uncertainties within each experiment and are given at $2 \sigma$. AUSZ2 zircon (38.9 Ma from unpublished chemical abrasion thermal ionization mass spectrometry (CA-TIMS) data, Boise State University) yielded a weighted mean ${ }^{206} \mathrm{~Pb} /{ }^{238} \mathrm{U}$ date of $37.91 \pm 1.36 \mathrm{Ma}(\mathrm{MSWD}=0.7, \mathrm{n}=12)$, which is within the limits (c. $2.6 \%$ ) of standardization accuracy.

\subsection{Fossil sample}

Fossil vertebrates were collected in the four localities at Río Bote and Río Santa Cruz. The specimens are curated at the Museo Regional Provincial Padre M. J. Molina of Río Gallegos, Santa Cruz Province. The material is still under study, so the identification of the taxa listed for each locality provided in this contribution is preliminary (including those mentioned by Fernicola et al., 2014). 


\section{Results}

\subsection{Stratigraphy of the dated sections}

The dated tuff samples come from the four outcrops of the SCF indicated in figures 1c and 2. Each outcrop was logged and tuffs located within a stratigraphic context. Sedimentary logs for each locality as well as the sedimentologic descriptions are provided by Fernicola et al. (2014). Because exposures are isolated and separated by tens of kilometers, and the absence of marker horizons, physical stratigraphic correlations among sections are difficult in most cases. One stratigraphic feature that can be used as a broad marker for correlation is the marine-terrestrial transition between the Estancia 25 de Mayo/Monte León and Santa Cruz formations. This transition is recognized in the field by the upward change from estuarine to terrestrial deposits, evidenced by the upward disappearance of the oyster shell beds, marine bioturbation, and tide-influenced sedimentary structures.

Figure 3. Field views of the tuff bearing sections. A) Upper part of the Rio Bote section showing the position of the dated sample RSC-27, located just at the top. B) View of the SCF at the upper part of the section at Yaten Huageno where the dated tuff sample RSC-20 is located. C) View of the 37 meter-thick exposure at Estancia El Tordillo within the Segundas Barrancas Blancas outcrop, with the sample CECA-2 highlighted. D) Lower part of the section at Barrancas Blancas. The section begins at the level of the Rio Santa Cruz with estuarine deposits of the $M L F$ followed by terrestrial strata of the SCF where the dated tuff sample RSC-7 is located.

The RSC-27 tuff is located at the top of the exposure of the SCF in the eastern margin of the Río Bote (Fig. 3a). The tuff is 120 meters above the base of the exposed section and about $170 \mathrm{~m}$ above the marine to estuarine Estancia 25 de Mayo Formation (Fig. 4). Above the main SCF outcrop where the RSC-27 tuff is located, several discontinuous outcrops complete a stratigraphic column of about 400 meters of SCF strata (Fig. 4). The RSC-27 tuff is $0.3 \mathrm{~m}$ thick and shows a fining upward trend from fine to very fine tuff. It is intercalated within tabular beds of mudstones and fine to medium grained lenticular or tabular sandstones (Fig. 3a) deposited on a fluvial floodplain. The tuff is composed mainly of glass shards, with a minor component of 
angular crystal fragments, especially quartz and plagioclase of volcanic origin, sparse biotite, magnetite, hornblende and volcanic lithic fragments (Fig. 5).

Figure 4. Physical correlation among studied localities including other key adjacent localities. Each section is positioned in relation to meters above sea level (masl) and the stratigraphic position of the fossil collection is indicated. EQS: Estancia Quién Sabe; ALP: Arroyo Los Perros; RB: Río Bote; YH: Yaten Huageno; SBB: Segundas Barrancas Blancas; ELBB: Estancia La Barrancosa Borehole; BB: Barrancas Blancas; MLNP: Monte León National Park.

The RSC-20 tuff is located in the Yaten Huageno section at Estancia El Refugio on the southern margin of the Río Santa Cruz valley (Figs. 1c and 2). There, an 85 meterthick exposure of the SCF shows abundant tuffaceous deposits. Underlying marine deposits are not exposed (Fig. 4). The analyzed tuff comes from the upper third of the section and is interbedded with siltstones and channelized lenticular sandstones (Fig. $3 b)$ deposited in a fluvial system. It is a poorly sorted, 0.45 meter-thick vitric tuff with a fining upward trend (fine to very-fine grain-size). Vitric particles are poorly sorted showing minute glass shards and pumice fragments up to coarse-sand size particles, suggesting some reworking may have occurred. Crystal fragments make up $15 \%$ of the rock, and are dominated by quartz and plagioclase, with minor biotite, magnetite and volcanic lithic fragments. Some calcite patches are observed, probably of pedogenic origin.

The CECA-2 tuff comes from a small outcrop in Estancia El Tordillo within the Segundas Barrancas Blancas outcrop belt (Figs. 2, 3c and 4). This is a 37 meter-thick section (Fig. 3c) located 4 km east of the thicker Estancia Cordon Alto section (Fig. 4) described by Fernicola et al. (2014). The CECA-2 tuff bed correlates with the lowermost portion of the Estancia Cordón Alto section. It is a fine-grained tuffaceous composite bed $1.3 \mathrm{~m}$ in thickness. Fe-rich patinas and mottling impart orange to brownish coloration, and its top is marked by carbonate-ferric concretions, features that can be related to pedogenesis. The orange coloration allows the physical correlation of this tuff over the whole Segundas Barrancas Blancas outcrop belt. The sample is a fine vitric tuff, with up to $20 \%$ of crystals and abundant vitric particles that are mainly pumice fragments. Crystals are angular and are dominated by quartz and plagioclase, with minor magnetite and pyroxene. 
Figure 5. Microphotographs of a thin section for sample RSC-27. Plagioclase (Pl), quartz ( $Q z)$ and biotite (Bt) are part of the primary crystal fragments. Glass shards $(G s)$ and pumice fragments $(P)$ are partially recrystallized. Groundmass is formed by fine-grained clay mineral alteration after glass. A) Plane-parallel light; B) Crossed nicols.

Figure 6. Different views of part of the zircon population of the sample CECA-2. A) View under a transmitted-light microscope; B) Cathodoluminescence image of cut and polished grains. The size of the laser spot $(30 \mu \mathrm{m})$ is indicated.

The RSC-7 tuff comes from the Estancia Aguada Grande section within the Barrancas Blancas outcrop (Figs. 1c, 2 and 4). This locality shows laterally extensive exposures of the SCF. The whole exposed thickness of the composite section is 150 meters, with the lowermost 25 meters representing estuarine deposits of the Monte León Formation (Fig. 3d). The sampled tuff bed is located at about 30 meters above the transition of the Monte León and Santa Cruz formations (Fig 3d). The tuff is a 3 meterthick massive bed with pale pink coloration and the sample comes from the base, where it is fine to medium grained. The tuff is interbedded within mudstone and siltstone floodplain deposits that show variable degrees of pedogenesis. The tuff contains in-situ vertebrate remains with rhizoliths at its top. This section has some stratigraphic features that allow correlation with coastal localities of the Monte León National Park (MLNP) sections, located about 55-60 km to the east (Figs. 1c, 2 and 4). In both regions the lowermost 40 meters of the SCF are dominated by pedogenically modified mudstones and some fine sandstones with abundant interbedded thick and laterally continuous finegrained tuff beds. The thickest tuff within this interval at the MLNP (called the CO tuff by Perkins et al., 2012) is similarly pale pink, and we tentatively correlate it with the RSC-7 tuff.

\subsection{U-Pb ages and section correlations}

The four analyzed samples yielded good-quality zircon populations (Fig. 6). U-Pb ages vary from $17.36 \pm 0.63 \mathrm{Ma}$ to $16.32 \pm 0.62 \mathrm{Ma}$ (Burdigalian), i.e. a 1.04 Ma age range (Table 1 and Fig. 7). Note that calibration uncertainties would impart systematic offsets to the ages (i.e. a different standardization would preserve the $\sim 1.0 \mathrm{Ma}$ age difference), and this difference in age exceeds propagated age uncertainties. The oldest age (sample RSC-27=17.36 $\pm 0.63 \mathrm{Ma}$ ) is at Río Bote whereas the youngest age (sample 
CECA-2 $=16.32 \pm 0.62 \mathrm{Ma}$ ) is in the central part of the study area at Segundas Barrancas Blancas (Fig. 1c). The other two samples from the Río Santa Cruz valley yielded similar ages (RSC-7=17.04 $\pm 0.55 \mathrm{Ma}$ and RSC-20=16.88 $\pm 0.65 \mathrm{Ma}$ ).

Table 1. U-Pb (LA-ICPMS) age results for the four analyzed zircon populations. MSWD: Mean Square Weighted Deviation.

Figure 7. Probability ages.

A west-east cross-section was constructed for the dated sections and other key nearby sections (Fig. 4), highlighting the topographic position and correlation elements. This cross-section is divided into three informal sectors: the western, central and eastern sectors. The western sector includes the Río Bote section and the nearby Arroyo Los Perros section previously reported by Cuitiño and Scasso (2010) and Cuitiño et al. (2012) (Fig. 4). The central sector includes the Yaten Huageno and Segundas Barrancas Blancas sections and the borehole Estancia La Barrancosa between the two. The eastern sector comprises the Barrancas Blancas and the Monte León National Park (MLNP) sections. Although a west to east sedimentological change (e.g. eastward grain size reduction) is observed for the SCF in the study area, we found no sedimentological attributes that could be used for regional stratigraphic correlation, such as welldeveloped paleosols, tuffs beds, major erosion surfaces or breaks in the depositional style. This problem is enhanced by the vertical sedimentological homogeneity of each section and extensive covered areas between localities. For this reason the stratigraphic correlation is based on topographic position and, when available, key marker beds such as the marine-terrestrial transition or (locally) laterally continuous tuff layers. The elevation of the base, top, and key beds for each section was used to highlight the altitude differences in the cross-section of figure 4 . Western localities lie at higher elevations (up to 750 masl) because they were uplifted during the Neogene Andean orogeny as part of the frontal monocline associated to the Andean fold-and-thrust belt (Ghiglione et al., 2009). In the central sector, marker beds for regional correlation are absent. There, the Estancia La Barrancosa borehole penetrated $62 \mathrm{~m}$ below the Río Santa Cruz valley floor without reaching the marine deposits that underlie the SCF (Fig. 4). This implies that the base of the outcrops of the SCF located at the margins of the Río Santa Cruz valley at this sector lie at least $62 \mathrm{~m}$ above the base of the unit. To the 
east, altitude differences are minor and the presence of local stratigraphic marker beds (e.g. thick tuffs) facilitates correlations.

The transition between the underlying marine deposits and the terrestrial SCF can be used as a broad correlation marker. This transition is defined in some cases by a change in sediment coloration (from gray/whitish to greenish/yellowish hue), and in some localities (e.g. at Arroyo Los Perros in the west and Monte León National Park in the east) it is marked by a monospecific oyster bed of Crassostrea orbignyi. This correlation, although diachronic (see below), is the only useful element since no other consistent marker bed or surface was found between central or western localities. The base of the SCF regionally crops out at eastern and western localities, while at midsector localities it lies in the subsurface (Fig. 4). The altitude differences of this transition is thought to be the result of post-depositional tectonism with uplift in the western sector and subsidence in the central sectors, while the eastern sector remained more or less balanced.

Based on the available ages from the literature (Cuitiño et al., 2012; Parras et al., 2012; Perkins et al., 2012) and our new ages, a chronostratigraphic correlation scheme was developed (Fig. 8) which includes the studied localities as well as other early Miocene mammal-bearing key localities (Marshall and Pascual, 1977; Tauber, 1994; Tejedor et al., 2006; Perkins et al., 2012). The vertical extension of each column represents time and is based on average long-term sedimentation rates of $\sim 150 \mathrm{~m} / \mathrm{Ma}$ (Perkins et al., 2012). This average is consistent for several localities in the west and east of the Austral Basin, where local estimated sedimentation rates do not deviate more than $47 \%$ from the regional average (Perkins et al., 2012). Considering that long-term sedimentation rates in foreland basins can readily vary between 50 and $1000 \mathrm{~m} / \mathrm{Ma}$ (Einsele 1992; Uba et al., 2007; Smith et al 2015) but that available sedimentation rates show no regional trend along the basin, it seems reasonable to use this average $150 \mathrm{~m} / \mathrm{Ma}$ rate as an approximate guide for estimating stratigraphic ages in the study area. The Estancia Quién Sabe, Arroyo Los Perros, and Río Bote sections (Fig. 4) in the western sector show the transitional passage of marine to terrestrial deposits, which was dated at 18.85 Ma (Cuitiño et al., 2012). The tuff age of 17.36 Ma for the Río Bote section, located $200 \mathrm{~m}$ above the SCF base, supports claims that the beginning of the deposition of sediments of the SCF in the western localities occurred earlier than that of eastern localities (Perkins et al., 2012; Bostelmann et al., 2013). The ages of mid-sector sections agree with their proposed higher stratigraphic positions, although the lack of 
the exposure of the base of the SCF prevents a definition of its basal chronostratigraphic extension.

\subsection{Associated vertebrate faunas}

A large number of fossil vertebrates were collected from Barrancas Blancas and Segundas Barrancas Blancas, and fewer specimens from Yaten Huageno and Río Bote. Overall, about $\sim 1,000$ taxonomically identifiable specimens were recorded, of which most are mammals. Many of the samples are in preparation and under study. The preliminary list of taxa used here was published by Fernicola et al. (2014), which will be refined and expanded with future collecting, preparation and systematic studies.

Figure 8. Chronostratigraphic correlation scheme for the Santacrucian sections investigated in this study and nearby localities of southern Patagonia. The geographic location of each site is indicated in figure 1. The trace of the scheme for localities in southern Santa Cruz is indicated in figure $1 C$. The vertical extension of the columns, calculated assuming an average sedimentation rate of $150 \mathrm{~m} / \mathrm{Ma}$, represents time $(\mathrm{Ma})$. Lithostratigraphic units are indicated in capital letters, excepting the Santa Cruz Formation.

At the Río Bote section, we recorded cingulates (Proeutatus sp.), rodents (Perymis sp.), and notoungulates (Adinotherium sp. and Notohippus sp.). All the specimens were collected from float at the base of the exposure (Fig. 4), which is dated at its top at 17.36 $\pm 0.63 \mathrm{Ma}$ (RSC-27). The Yaten Huageno locality includes cingulates (Cochlops sp., Proeutatus sp., Prozaedyus sp. and Stenotatus sp.), sloths (Hapalops sp., Nematherium sp.), rodents (Perymis sp. and Neoreomys sp.), and notoungulates (Nesodon sp. and Interatherium sp.). All the specimens from Yaten Huageno come from levels located below the dated tuff (RSC-20, 16.88 $\pm 0.65 \mathrm{Ma}$ ). Specimens from the Segundas Barrancas Blancas outcrop belt come from levels located above the dated tuff (CECA-2, 16.32 \pm 0.62); they include cingulates (Eucinepeltus sp., Cochlops sp., Propalaehoplophorus sp., Proeutatus sp., Prozaedyus sp. and Stenotatus sp.,), sloths (Hapalops sp.), rodents (Neoreomys sp., Perimys sp., and Prolagostomus sp.), notoungulates (Nesodon sp., Adinotherium sp., and Interatherium sp.), litopterns (Thoatherium sp), astrapotheres (Astrapotherium sp.), and marsupials (Palaeothentes sp. and Abderites sp.). The specimens recovered from Barrancas Blancas come from levels located above the dated tuff (RSC-7, 17.04 \pm 0.55 Ma). Identified taxa include 
cingulates (Propalaehoplophorus sp., Proeutatus sp, Prozaedyus sp. and Stenotatus sp.), sloths (Hapalops sp.), rodents (Acaremys sp. and Neoreomys sp.), notoungulates (Nesodon sp. and Adinotherium sp.), litopterns (Thoatherium sp.), astrapotheres (Astrapotherium sp.), marsupials (Palaeothentes sp.), and primates (Homunculus sp.).

\section{Discussion}

\subsection{Geochronology}

The new results are consistent with previous estimated ages for the SCF and adjacent units. In the western sector, at the Lago Argentino region where the Río Bote section is located, Cuitiño et al. (2012) dated the basal beds of the SCF at $18.85 \pm 0.3 \mathrm{Ma}$ which is consistent with our age of 17.36 Ma located about 170 meters higher in the section (Fig. 4). In the eastern sector, close to the coastal localities, our age of 17.04 $\pm 0.55 \mathrm{Ma}$ for the RSC-7 tuff at Barrancas Blancas is consistent with the ${ }^{40} \mathrm{Ar} /{ }^{39} \mathrm{Ar}$ 17.7-17.2 Ma ages reported by Perkins et al. (2012) for the lower stratigraphic levels of the SCF in Monte León (Fig. 8). We reiterate that standardization errors could shift ages older or younger, but such systematic shifts would not affect the relative age differences among localities. The U-Pb dates indicate that the sedimentary succession of the SCF in the four localities that we studied range at least from 17.36 to $16.32 \mathrm{Ma}$. Using the average sedimentation rate of $150 \mathrm{~m} / \mathrm{Ma}$ to calculate sedimentological ages above and below each dated tuff, the age range of the SCF in the study area can be expanded, from $\sim 18.20$ to $~ 15.63 \mathrm{Ma}$. These ages allows us to discuss correlations among them and with other localities outside the study area.

The Río Bote section is bracketed between $\sim 18.20 \mathrm{Ma}$ and 17.36 Ma (Fig. 8). The basal/older part of this section is older than the coastal and Río Santa Cruz sections, synchronous with the lower/basal parts of the Karaiken and Lago Posadas sections (Perkins et al., 2012; Cuitiño et al., 2015), and the lower section of the Pinturas Formation in Estancia El Carmen locality, which was dated at 17.99 Ma near its base (Perkins et al. 2012). In Chile, the older part of the Río Bote section would correlate with the 100 meter-thick section of the SCF in the Sierra Baguales (northeast of Torres del Paine), whose upper levels have a maximum age of 18.23 Ma (Bostelmann et al., 2013). The uppermost/younger part of the Río Bote section chronologically overlaps the lower part of the sections from the Atlantic coast, and the lower part of the Karaiken and Lago Posadas sections (Fig. 8). 
In the Río Santa Cruz, the sedimentary succession from Barrancas Blancas extends from $\sim 17.25$ to $\sim 16.49 \mathrm{Ma}$ (Burdigalian), which is likely synchronous with the succession at Yaten Huageno. The Segundas Barrancas Blancas section appears younger, extending from 16.32 to $15.63 \mathrm{Ma}$ (late Burdigalian - early Langhian). The integration of our chronological scheme with that proposed by Perkins et al. (2012) shows that the successions from Barrancas Blancas and Yaten Huageno were deposited approximately synchronously with respect to those observed in the Atlantic region between Monte León and Río Gallegos/Killik Aike Norte (17.71 to 15.90 Ma). The basal/older part of Barrancas Blancas and Yaten Huageno chronologically overlaps the Portezuelo Sumich Norte section of the Pinturas Formation in the northwest of the Santa Cruz Province (Fig. 8). The succession of the SCF at Segundas Barrancas Blancas chronologically overlaps the stratigraphically higher portions of the SCF at Monte León, Cerro Observatorio, Killik Aike Norte, and Cabo Buen Tiempo sections to the east, as well as the Karaiken section in the west. The uppermost part of the Segundas Barrancas Blancas section is certainly younger than all other dated exposures of the SCF in Santa Cruz Province, excepting the Lago Posadas section which was dated at $14 \mathrm{Ma}$ at its top (Blisniuk et al., 2005). Beyond the Santa Cruz Province, the upper parts of the Segundas Barrancas Blancas section may be equivalent in age to, or slightly younger than, the Pilcaniyeu Ignimbrite of the Collón Cura Formation in Río Negro and Neuquén provinces (Fig. 1a) (the latter dated by single-crystal $\mathrm{Ar}^{40} / \mathrm{Ar}^{39}$ to $15.7 \mathrm{Ma}$, Flynn and Swisher, 1995; Madden et al., 1997), and would correlate with the Río Frías Formation in the Alto Río Cisnes (Aysén Region, Chile; Fig. 1a), dated at 16.5 Ma at its base (Flynn and Swisher, 1995) and with a fauna very similar to that of the Collón Cura Formation (Bostelmann et al., 2012).

For the Segundas Barrancas Blancas and Yaten Huageno sections there are no other stratigraphic or dated intervals within each section or in neighbor areas that can be used for chronostratigraphic control. Instead, this control is available at the Río Bote and Barrancas Blancas sections. The age of the Río Bote section (17.36 Ma) is completely consistent with the estimated age for the base of the SCF obtained for that region in Estancia Quién Sabe (18.85 Ma; Cuitiño et al., 2012), about 20 km west of Río Bote, and with the average sedimentation rate for the SCF ( $150 \mathrm{~m} / \mathrm{Ma}$; Perkins et al., 2012).

The age of 17.04 Ma obtained for the tuff RSC-7 at Barrancas Blancas poses some chronologic inconsistencies because it lies only 30 meters above the transition between the Monte León and Santa Cruz formations (Fig. 4). Using the average sedimentation 
rate of $150 \mathrm{~m} / \mathrm{Ma}$, the base of the SCF at Barrancas Blancas should be about $17.25 \mathrm{Ma}$, whereas using the slowest sedimentation rate proposed in the region $(60-80 \mathrm{~m} / \mathrm{Ma}$ for basal SCF; Perkins et al., 2012) the age might be as old as $~ 17.45$ Ma. Both limits are $\sim 0.5$ to $0.25 \mathrm{Ma}$, respectively, younger than the $17.7 \mathrm{Ma}$ age reported by Perkins et al. (2012) for the Monte León section. The basal SCF age at Monte León is coherent with

${ }^{87} \mathrm{Sr} /{ }^{86} \mathrm{Sr}$ ages of about $18 \mathrm{Ma}$ for marine levels positioned at $\sim 60 \mathrm{~m}$ below the transition between the Monte León and Santa Cruz formations (Parras et al., 2012). Barrancas Blancas is located only about $60 \mathrm{~km}$ west of Monte León, so age differences for the marine/terrestrial transition between both sites are expected to be small; no facies changes or important discontinuities were found within this interval at Barrancas Blancas. Consequently, we interpret the measured age for tuff RSC-7 to be slightly too young, and that the true age is more likely $\sim 17.4 \mathrm{Ma}$. This age is within our analytical error, but implies an age for the basal SCF of $\sim 17.7 \mathrm{Ma}$ and is more consistent with regional chronologies.

\subsection{Vertebrate paleontology}

\subsubsection{Río Bote}

Fossils in situ from Río Bote locality were collected in the lower 25 meters of the sedimentary succession; therefore, their temporal assignment would be between $\sim 18.20$ to $18.00 \mathrm{Ma}$ (Fig. 8). The sparse faunal sample, prevents deep comparisons with other assemblages. However, the remarkable occurrence of the notoungulate Notohippus correlates the Río Bote mammal assemblage to the Notohippideen étage of Ameghino (1900-02, 1906). Ameghino (1906) restricted this étage to the Karaiken region, located about $30 \mathrm{~km}$ to the north of the Río Bote section (Fig. 1c); however, Fernicola et al. (2014) provide convincing evidence that some of the specimens assigned by Ameghino (1900-02, 1906) to the Notohippidian most likely were collected in Río Bote. At Karaiken, Marshall and Pascual (1977) distinguished a Notohippidian fauna in the lowest levels ( 18.5 Ma; Fleagle et al., 2012), and a Santacrucian fauna higher in the section (younger than 17.71 Ma; Fleagle et al., 2012). According to Marshall and Pascual (1977), Ameghino's specimens lack precise stratigraphic provenance and, therefore, cannot be reliably assigned to either of these two faunal levels. Marshall and Pascual (1977) also described a Notohippidian assemblage from Cerro Centinela, situated $30 \mathrm{~km}$ southwest of the Río Bote section (Fig. 1c). There, the fossil specimens were recovered from the lower 20 meters of the continental sedimentary succession of 
the SCF that overlies the marine Centinela Formation (=Estancia 25 de Mayo; Cuitiño and Scasso, 2010). Considering that the marine-terrestrial transition in this region was dated at about 18.85 Ma (Cuitiño et al., 2012) together with the average sedimentation rate used here (150 m/Ma), the Notohippidian assemblage of Cerro Centinela would be bracketed between 18.85 and $\sim 18.70 \mathrm{Ma}$ (Fig. 8). In summary, the known time interval for the Notohippidian in western Santa Cruz Province should be bracketed between $\sim 18.85$ and $\sim 18.00 \mathrm{Ma}$ (Table 2).

Table 2. Chronology of the Miocene faunal assemblages of southern South America mentioned in the text.

This temporal span provides evidence that the Notohippidian assemblage is partially synchronous with the post-Colhuehuapian and pre-Santacrucian fauna of Sierra Baguales (sensu Bostelmann et al., 2013). The Notohippidian is also partially synchronous with the Pinturan fauna as defined by Kramarz and Bellosi (2005) in the lower and middle sections of the Pinturas Formation at Río Pinturas (northwest Santa Cruz Province), and by Kramarz et al. (2010) in the upper part of the Colhue-Huapi Member of the Sarmiento Formation at Gran Barranca (southern Chubut Province). The upper limit of the Colhue Huapi Member was bracketed between 19.04 and 18.62 Ma (Dunn et al., 2013); in Río Pinturas the oldest beds of the Pinturas Formation were placed at 17.99 Ma, while the age of the youngest beds is uncertain (Perkins et al., 2012; Fleagle et al., 2012). That is, the temporal span for the Pinturan would be between 19 and as young as $18 \mathrm{Ma}$.

Although a detailed taxonomic reconciliation of the Notohippidian, Pinturan and Santacrucian faunas exceeds the objective of this work, some preliminary remarks are worthwhile. As mentioned above, we used the presence of Notohippus to assign a Notohippidian age to the fauna from Río Bote. The fact that this taxon has never been recorded in the Pinturan or the Santacrucian faunal assemblages, together with the temporal scenario herein proposed, is consistent with the view that the differences between the Notohippidian and Pinturan faunal assemblages must reflect ecological or geographic, rather than temporal, factors. In agreement with Marshall et al. (1983 and references therein), the Notohippidian and Pinturan faunas would represent chronologically earlier assemblages than the Santacrucian faunas of the Río Santa Cruz, along the Atlantic coast, and on the north shore of Río Gallegos. This view is consistent 
with the existence of a Santacrucian fauna in the upper levels of Karaiken (Marshall and Pascual, 1977) and the Pinturas Formation (Kramarz and Bellosi, 2005).

\subsubsection{Río Santa Cruz}

Fossils from Yaten Huageno and Segundas Barrancas Blancas were collected along the entire stratigraphic column, while in Barrancas Blancas they were collected only above the dated tuff. The time span of these sections ( 17.45 to $\sim 15.63 \mathrm{Ma})$ indicates that the associated faunal assemblage is synchronous and partially younger than the faunal assemblages of the eastern coastal and Río Gallegos localities, from Monte León to Killik Aike Norte (Fig. 8). At the genus level we have not detected differences between the faunal assemblages of the three localities of the Río Santa Cruz and those from the eastern coastal exposures (Vizcaíno et al., 2012 and references therein). The taxa mentioned in section 5.4 were identified from the Río Santa Cruz localities by Ameghino (1887; 1889), excepting a new record of the primate Homunculus sp. (Fernicola et al., 2014), described only for the eastern coastal exposures of the Santa Cruz Province (Kay et al., 2012b and references therein).

The SCF also chronologically overlaps with other units external to the Santa Cruz Province, such as the Collón Cura and Río Frías formations, which bear Colloncuran (Vucetich et al., 1993; Bond and Kramarz, 2008; González et al., 2013) and Friasian (Marshall and Salinas, 1990 a,b; Bostelmann et al., 2012) faunas respectively. Taxonomic differences with the Santacrucian faunas (a somewhat different rodent faunal composition - Vucetich et al, 1993- and the presence of distinctive primates not found in the Santa Cruz Formation - Kay et al., 1998-), must therefore reflect ecological or geographic, rather than temporal, differences.

Ongoing additional fieldwork, new collections and new geochronologic data in poorly investigated areas of the Santa Cruz Province will increase the number of fossil specimens with precise chronostratigraphic control, especially localities in the western (Andean) refion and north of Río Santa Cruz (east of Lago Cardiel, for example), to evaluate their faunal compositions and temporal correlations. They will also provide data that can shed light on the probable paleoenvironmental and paleobiogeographic scenarios.

\section{Conclusions}


New U-Pb geochronologic data are provided for fossil mammal-bearing sections of the Santa Cruz Formation in southern Santa Cruz Province, Patagonia. Four absolute ages as well as estimates of sedimentation rates, and the stratigraphic position of the collected faunas are provided for the Río Bote and three localities of the Río Santa Cruz valley (from west to east, Yaten Huageno, Segundas Barrancas Blancas and Barrancas Blancas). Taken together, these sections span the temporal interval from $\sim 18.20$ to $\sim 15.63 \mathrm{Ma}$ (Burdigalian), which is in agreement with the ages of the underlying "Patagoniense" marine deposits, and with other dated sections of the SCF to the east.

The Notohippidian fauna ( 19.00 to $\sim 18.00 \mathrm{Ma}$ ) of the western localities (Río Bote, Karaiken, and Cerro Centinela) is synchronous with the Pinturan fauna ( 19.00 to $\sim 18.00 \mathrm{Ma}$ ) of the Río Pinturas localities, and both are older than the Santacucian faunas of the Río Santa Cruz ( 17.22 to $\sim 15.60 \mathrm{Ma}$ ) and eastern costal localities of the Santa Cruz Province ( $\sim 18.00$ to $\sim 16.20 \mathrm{Ma})$. Collectively, the Santacrucian localities of the Río Santa Cruz valley have a temporal span that is synchronous with the eastern coastal localities, the Friasian fauna ( 16.50 Ma) of the Aysén region of Chile and the Colloncuran fauna ( 15.70 Ma) of Río Negro Province in northern Patagonia.

\section{Acknowledgments}

We thank to Dirección de Patrimonio Cultural, and Museo Regional Provincial "Padre M. J. Molina” (Río Gallegos, Santa Cruz Province) for allowing us to work in the province and their support during several field seasons; to Natalia Kovacic, Roberto Díaz, Ariel Ivovich, Alfredo Albertengo, and the Battini family for their hospitality during the field work. We thank especially Néstor Toledo, Verónica Krapovickas, Leonel Acosta, Jonathan Perry, Santiago Hernández del Pino, Laura Chornogubsky, Nahuel Muñoz, and Lauren Gonzalez for their collaboration during the field works, and James Crowley for assistance with zircon dating. This is a contribution to the projects UNLu CCD-CD: 054/12 and CONICET- PIP 00781 (JCF), UNLP N750 and ANPCyTPICT 0389 (SFV), National Science Foundation grants EAR0851272 (RFK), EAR1348259 (RFK) and EAR1349749 (MJK), National Geographic Society 9167-12 (RFK), and Boise State University (MJK). Suggestions from the reviewers S. Casadío and M.S. Raigemborn are greatly appreciated.

\section{References}


Ameghino, C., 1890. Exploraciones geológicas en La Patagonia. Boletín Instituto Geográfico Argentino 11, 3-46.

Ameghino, F., 1887. Enumeración sistemática de las especies de mamíferos fósiles coleccionados por Carlos Ameghino en los terrenos eocenos de la Patagonia y depositados en el Museo de La Plata. Boletín Museo de La Plata 1, 1-26.

Ameghino, F., 1889. Contribución al conocimiento de los mamíferos fósiles de la República Argentina. Actas de la Academia Nacional de Ciencias 6, 1-1028.

Ameghino, F., 1900-1902. L'age des formations sédimentaires de Patagonie. Anales de la Sociedad Científica Argentina 50, 109-130, 145-165, 209-229; 51: 20-39, 65-91; 52: 189-197, 244-250; 54: 161-180, 220-249, 283-342.

Ameghino, F., 1906. Les formations sédimentaires du Crétacé Superieur et du Tertaire de Patagonie avec un parallele entre leurs faunes mammalogiques et celles de l'ancien continent. Anales del Museo Nacional de Buenos Aires 15, 1-568.

Bertels, A., 1970. Sobre el "Piso Patagoniano" y la representación de la época del Oligoceno en Patagonia Austral, República Argentina. Revista de la Asociación Geológica Argentina, 25, 496-501.

Bertels, A., 1980. Estratigrafía y foraminíferos (Protozoa) bentónicos de la Formación Monte León (Oligoceno) en su área tipo, provincia de Santa Cruz, República Argentina. II Congreso Argentino de Paleontología y I Congreso Latinoamericano de Paleontología, Actas, 2, 213-273.

Biddle, K.T., Uliana, M.A., Mitchum Jr., R.M., Fitzgerald, M.G., Wright, R.C., 1986. The stratigraphic and structural evolution of the central and eastern Magallanes Basin, southern South America. In: Allen and Homewood (Eds.): Foreland Basins, Special Publication International Association of Sedimentologists 8, 41-61. Blackwell. 
Blisniuk, P.M., Stern, L.A., Chamberlain, C.P., Idleman, B., Zeitler, P.K., 2005.

Climatic and ecologic changes during Miocene surface uplift in the Southern

Patagonian Andes. Earth and Planetary Science Letters 230, 125-142.

Bond, M.; Kramarz, A.G. 2008. On some Toxodontidae from the Colloncuran Salma (middle Miocene) of Pilcaniyeu Viejo, Río Negro Province, Argentina. In Congreso Latinoamericano de Paleontología de Vertebrados, No. 3, Resúmenes: p. 26. Neuquén.

Bostelmann, E.; Bobe, R.; Carrasco, G.; Alloway, B.V.; Santi-Malnis, P.; Mancuso, A.; Agüero, B.; Alem- seged, Z.; Godoy, Y. 2012. The Alto Río Cisnes fossil fauna (Río Frías Formation, early Middle Miocene, Friasian SALMA): a keystone and paradigmatic vertebrate assemblage of the South American fossil record. Abriendo ventanas al pasado. In Abriendo ventanas al pasado (Leppe, M.; Aravena, J.C.; VillaMartínez, R.; editors). Simposio de Paleontología en Chile, No. 3, Resúmenes, 46-49.

Bostelmann, J.E., Le Roux, J.P., Vásquez, A., Gutiérrez, N.M., Oyarzún, J.L., Carreño, C., Torres, T., Otero, R., Llanos, A., Fanning, C.M., Hervé, F., 2013. Burdigalian deposits of the Santa Cruz Formation in the Sierra Baguales, Austral (Magallanes) Basin: age, depositional environment and vertebrate fossils. Andean Geology 40, 458489.

Bown, T.M, Larriestra, C.N., 1990. Sedimentary paleonevironments of fossil platyrrhine localities, Miocene Pinturas Formation, Santa Cruz Province, Argentina. Journal of Human Evolution 19, 87-119.

Bown, T.M., Fleagle, J. G., 1993. Systematics, biostratigraphy, and dental evolution of the Palaeothentidae, later Oligocene to early-middle Miocene (Deseadan-Santacrucian) caenolestoid Marsupials of South America. Journal of Paleontology 67, Supplement 2, $1-76$.

Brinkman, P., 2003. Bartholomew James Sulivan's discovery of fossil vertebrates in the Tertiary beds of Patagonia. Archives of Natural History, 30, 56-74. 
Brinkman, P.D., Vizcaíno, S.F., 2014. Clemente Onelli's sketch map and his first-hand, retrospective account of an early fossil-hunting expedition along the Río Santa Cruz, southern Patagonia, 1888-1889. Archives of Natural History 41, 326-337

Chiesa, J.O., Camacho, H.H., 1995. Litoestratigrafía del Paleógeno marino en el noroeste de la provincia de Santa Cruz, Argentina. Monografías de la Academia Nacional de Ciencias Exactas, Físicas y Naturales de Buenos Aires 11, 9-15.

Cuitiño, J.I., Ventura Santos, R., Alonso Muruaga, P., Scasso, R.A., 2015. Srstratigraphy and sedimentary evolution of early Miocene marine foreland deposits at the northern Austral (Magallanes) Basin, Argentina. Andean Geology 43, 364-385.

Cuitiño, J.I., Pimentel, M.M., Ventura Santos, R., Scasso, R.A., 2012. High resolution isotopic ages for the "Patagoniense" transgression in southwest Patagonia: stratigraphic implications. Journal of South American Earth Sciences 38, 110-122.

Cuitiño, J.I., Scasso, R.A., 2010. Sedimentología y paleoambientes del Patagoniano y su transición a la Formación Santa Cruz al sur del Lago Argentino, Patagonia Austral. Revista de la Asociación Geológica Argentina 66, 406-417.

Dunn, R.E., Madden, R.H., Kohn, M.J., Schmitz, M.D., Strömberg, C.A.E., Carlini, A.A., Ré, G.H., Crowley, J. 2013. A new chronology for middle Eocene-early Miocene South American Land Mammal Ages. Geological Society of America Bulletin 125, $539-555$.

Einsele, G., 1992. Sedimentary basins. Evolution, facies and sedimentary budget. Springer Verlag, $629 \mathrm{p}$.

Fernicola, J.C., Cuitiño, J.I., Vizcaíno, S.F., Bargo, M.S., Kay, R.F., 2014. Fossil localities of the Santa Cruz Formation (Early Miocene, Patagonia, Argentina) prospected by Carlos Ameghino in 1887 revisited and the location of the Notohippidian. Journal of South American Earth Sciences 52, 94-107. 
Feruglio, E., 1938. Relaciones estratigráficas entre el Patagoniano y el Santacruciano en la Patagonia Austral. Revista del Museo de La Plata, Geología 4, 129-159

Feruglio, E. 1949. Descripción Geológica de la Patagonia. Dirección General de Yacimientos Petrolíferos Fiscales, 3 Tomos, T1: 1-323; T2: 1-349; T3: 1-331. Buenos Aires.

Fleagle, J.G., Bown, T.M., Swisher, C., Buckley, G., 1995. Age of the Pinturas and Santa Cruz Formations. VI Congreso Argentino de Paleontología y Bioestratigrafía, Actas, 129-135. Trelew.

Fleagle, J.G., Perkins, M.E., Heizler, M.T., Nash, B., Bown, T.M., Tauber, A.A., Dozo, M.T., Tejedor, M.F., 2012. Absolute and relative ages of fossil localities in the Santa Cruz and Pinturas Formations. In: Vizcaíno, S.F., Kay, R.F., Bargo, M.S. (Eds.), Early Miocene Paleobiology in Patagonia: High-Latitude Paleocommunities of the Santa Cruz Formation. Cambridge University Press, Chapter 3, 41-58.

Flynn, J.J., Swisher, C.C., 1995. Cenozoic South American land mammal ages: correlation to global geochronologies. In Geochronologies, Time Scales, and Global Stratigraphic Correlation (Berggren, W.A.; Kent, D.V.; Hardenbol, J.; editors). Society for Sedimentary Geology, Special Publication, 54, 317-333.

Fosdick, J.C., Grove, M., Hourigan, J.K., Calderón, M., 2013. Retroarc deformation and exhumation near the end of the Andes, southern Patagonia. Earth and Planetary Science Letters 361, 504-517.

Furque, G., Camacho, H.H., 1972. El Cretácico Superior y terciario de la región austral del Lago Argentino (Provincia de Santa Cruz). 4 Jornadas Geológicas Argentinas, 6175. Buenos Aires.

Furque, G., 1973. Descripción geológica de la Hoja 58b, Lago Argentino, provincia de Santa Cruz. Servicio Nacional Minero Geológico, Boletín 140, 1-51. 
Ghiglione, M.C, Suarez, F., Ambrosio, A., Da Poian, G., Cristallini, E. O., Pizzio, F., Reinoso, R. M., 2009. Structure and evolution of the Austral Basin fold-thrust belt, southern patagonian Andes. Revista de la Asociación Geológica Argentina 65, 215-226.

Giacosa, R., Franchi, M., 2001. Hojas Geológicas 4772-III y 4772-IV, Lago Belgrano y Lago Posadas. Provincia de Santa Cruz. Instituto de Geología y Recursos Minerales, Servicio Geológico Minero Argentino. Boletín 256: 68 p. Buenos Aires.

González Ruiz, L.R.; Scillato-Yané, G.J. 2009. A new Stegotheriini (Mammalia, Xenarthra, Dasypodidae) from the 'Notohippidian' (early Miocene) of Patagonia, Argentina. Neues Jahrbuch für Geologie und Paläontologie Abhandlungen 252, 81-90.

Kay, R.F., Johnson, D.J., Meldrum, D.J., 1998. A new pitheciin primate from the middle Miocene of Argentina. American Journal of Primatology 45, 317-336.

Kay, R.F., Vizcaíno, S.F., Bargo, M.S., 2012a. A review of the paleoenvironment and paleoecology of the Miocene Santa Cruz Formation. In: Vizcaíno, S.F., Kay, R.F., Bargo, M.S. (Eds.), Early Miocene Paleobiology in Patagonia: High-Latitude Paleocommunities of the Santa Cruz Formation. Cambridge University Press, Chapter $17,331-365$.

Kay, R.F., Perry, J.M.G., Malinzak, M., Allen, K.L., Kirk, E.Ch., Plavcan, J.M., Fleagle, J.G., 2012b. Paleobiology of Santacrucian primates. In: Vizcaíno, S.F., Kay, R.F., Bargo, M.S. (Eds.), Early Miocene Paleobiology in Patagonia: High-Latitude Paleocommunities of the Santa Cruz Formation. Cambridge University Press, Chapter $16,306-330$.

Kramarz, A.G., Bellosi, E.S., 2005. Hystricognath rodents from the Pinturas Formation, Early-Middle Miocene of Patagonia; biostratigraphic and paleoenvironmental implications. Journal of South American Earth Sciences 18, 199-212.

Kramarz, A.G.; Vucetich, M.G.; Carlini, A.A.; Ciancio, M.R.; Abello, M.A.; Deschamps, M.C.; Gelfo, J.N., 2010. A new mammal fauna at the top of the Gran Barranca sequence and its biochronological significance. In: The Paleontology of Gran 
Barranca: Evolution and Environmental Change trough the Middle Cenozoic of Patagonia (Madden, R.H.; Carlini, A.A.; Vucetich, M.G.; Kay, R.F.; editors).

Cambridge University Press, 260-273. Cambridge.

Ludwig, K.R., 2003. User's Manual for Isoplot 3.00. Berkeley Geochronology Center: Berkeley, CA, 70 p.

Madden, R.H.; Guerrero J.; Kay R.F.; Flynn, J.J.; Swisher III, C.C., Walton, A.H., 1997. The Laventan Stage and Age. Vertebrate Paleontology in the Neotropics. In: F.R. Kay; R.H. Madden; R.L. Cifelli \& J.J. Flynn (eds.) Vertebrate Paleontology in the Neotropics. The Miocene Fauna of La Venta, Colombia, Smithsonian Institution Press, p. $499-519$.

Marshall, L.G., 1976. Fossil localities for Santacrucian (Early Miocene) mammals, Santa Cruz Province, Southern Patagonia, Argentina. Journal of Paleontology 50, 11291142.

Marshall, L.G., Pascual, R., 1977. Nuevos marsupiales Caenolestidae del Piso "Notohipidense" (SW de Santa Cruz, Patagonia) de Ameghino. Sus aportaciones a la cronología y evolución de las comunidades de mamíferos sudamericanos. Publicaciones del Museo Municipal de Ciencias Naturales de Mar del Plata "Lorenzo Scaglia”, 2, 91122.

Marshall, L.G., Salinas, P., 1990a. Stratigraphy of the Río Frías Formation (Miocene), along the Alto Río Cisnes, Aisén, Chile. Revista Geológica de Chile 17, 57-87.

Marshall, L.G., Salinas, P., 1990b. Vertebrados continentales del Mioceno inferior de Magallanes, Chile. Anales del Instituto de la Patagonia, Serie Ciencias Naturales 19, 27 38.

Marshall, L.G., Hoffstetter, R., Pascual, R., 1983. Mammals and Stratigraphy: Geochronology of the Continental Mammal-bearing Tertiary of South America. In: Paleovertebrata, Mémoire Extraordinaire, pp. 1-76. 
Marshall, L.G., Drake, R.E., Curtis, G.H., Butler, R.F., Flanagan, K.M., Naeser, Ch.W., 1986. Geochronology of type Santacrucian (middle Tertiary) Land Mammal Age, Patagonia. The Journal of Geology 94, 449-457.

Matheos, S.D. Raigemborn, M.S., 2012. Sedimentology and paleoenvironments of the Santa Cruz Formation. In: Vizcaíno, S.F., Kay, R.F., Bargo, M.S. (Eds.), Early Miocene Paleobiology in Patagonia: High-Latitude Paleocommunities of the Santa Cruz Formation. Cambridge University Press, Chapter 4, 59-82.

Parras, A., Griffin, M., Feldmann, R., Casadío, S., Schweitzer, C., Marenssi, S., 2008. Correlation of marine beds based on Sr-and Ar-date determinations and faunal affinities across the Paleogene/Neogene boundary in southern Patagonia, Argentina. Journal of South American Earth Sciences, 26, 204-216.

Parras, A., Dix, G.R., Griffin, M., 2012. Sr-isotope chronostratigraphy of Paleogene/Neogene marine deposits: Austral Basin, southern Patagonia (Argentina). Journal of South American Earth Sciences 37, 122-135.

Perkins, M.E., Fleagle, J.G., Heizler, M.T., Nash, B., Bown, T.M., Tauber, A.A., Dozo, M.T., 2012. Tephrochronology of the Miocene Santa Cruz and Pinturas Formations, Argentina. In: Vizcaíno, S.F., Kay, R.F., Bargo, M.S. (Eds.), Early Miocene Paleobiology in Patagonia: High-Latitude Paleocommunities of the Santa Cruz Formation. Cambridge University Press, Chapter 2, 23-40.

Ramos, V.A., 1989. Andean foothills structures in northern Magallanes Basin, Argentina. American Association of Petroleum Geologists 73, 887-903.

Raigemborn, M.S., Matheos, S.D., Krapovickas, V., Vizcaíno, S.F., Bargo, M.S., Kay, R.F., Fernicola, J.C., Zapata, L., 2015. Paleoenvironmental reconstruction of the coastal Monte Léon and Santa Cruz formations (early Miocene) at Rincón del Buque, southern Patagonia: A revisited locality. Journal of South American Earth Sciences 60, 31-55.

Simpson, G.G., 1940. Review of the mammal-bearing Tertiary of South America. Proceedings of the American Philosophical Society, 83, 649-709. 
Sláma, J., Košler, J, Condon, D.J., Crowley, J.L., Gerdes, A., Hanchar, J.M.,

Horstwood, M.S.A., Morris, G.A., Nasdala, L., Norberg, N., Schaltegger, U., Schoene, B. Tubrett, M.N, Whitehouse, M.J., 2008. Plešovice zircon - A new natural reference material for $\mathrm{U}-\mathrm{Pb}$ and $\mathrm{Hf}$ isotopic microanalysis. Chemical Geology, 249, 1-35.

Smith, D.G., Bailey, R.J., Burgess, P.M., Fraser, A.J., 2015. Strata and time: probing the gaps in our understanding. Geological Society, London, Special Publications, 404, $1-326$.

Tauber, A.A., 1994. Estratigrafía y vertebrados fósiles de la Formación Santa Cruz (Mioceno inferior) en la costa atlántica entre las rías del Coyle y Río Gallegos, Provincia de Santa Cruz, República Argentina. Unpublished thesis, Facultad de Ciencias Exactas, Físicas y Naturales, Universidad Nacional de Córdoba, República Argentina.

Tauber, A.A., 1997. Bioestratigrafía de la Formación Santa Cruz (Mioceno inferior) en el extremo sudeste de la Patagonia. Ameghiniana, 34, 413-426.

Tejedor, M.F., Tauber, A.A., Rosenberger, A.L., Swisher, C.C., Palacios, M.E., 2006. New primate genus from the Miocene of Argentina. Proceedings of the National Academy of Sciences USA, 103, 5437-5441.

Uba, E.C., Strecker, M.R., Schmitt, A.K., 2007. Increased sediment accumulation rates and climatic forcing in the central Andes during the late Miocene. Geology 35, 979982, doi: 10.1130/G224025A.

Ugarte, F.R.E., 1956. El grupo Río Zeballos en el flanco occidental de la Meseta Buenos Aires (Provincia de Santa Cruz). Revista de la Asociación Geológica Argentina 11, 202-216.

Vizcaíno, S.F., Kay, R.F., Bargo, M.S., 2012. Early Miocene Paleobiology in Patagonia: High-Latitude Paleocommunities of the Santa Cruz Formation. Cambridge University Press, 378 pp. 
Vucetich, M.G., Mazzoni, M.M., Pardiñas, U.F.J. 1993. Los roedores de la Formación Collón Cura (Mioceno Medio), y la Ignimbrita Pilcaniyeu. Cañadón del Tordillo, Neuquén. Ameghiniana 30, 361-381.

White, J.D.L., Houghton, B.F., 2006. Primary volcaniclastic rocks. Geology 34, 677680. 


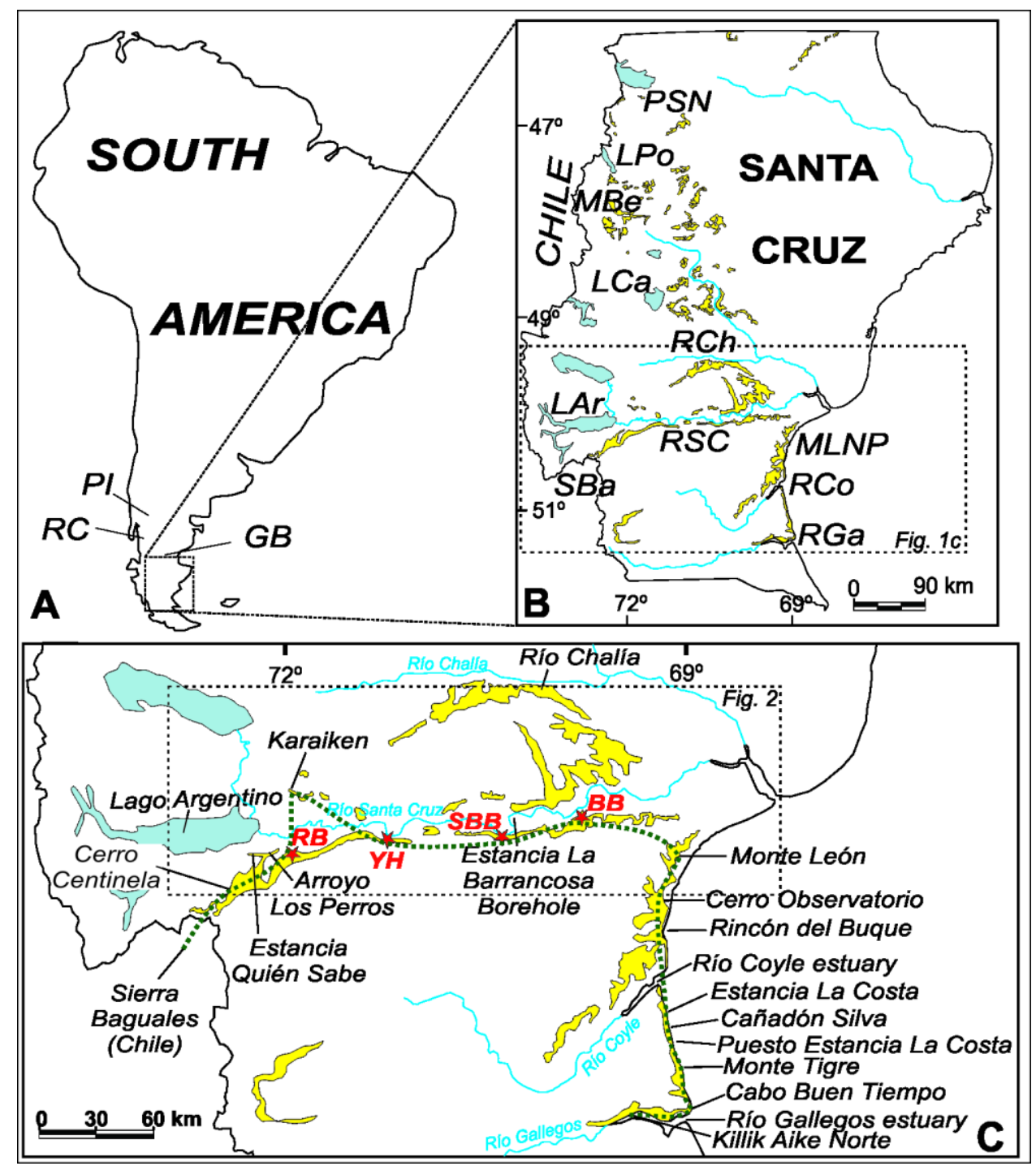




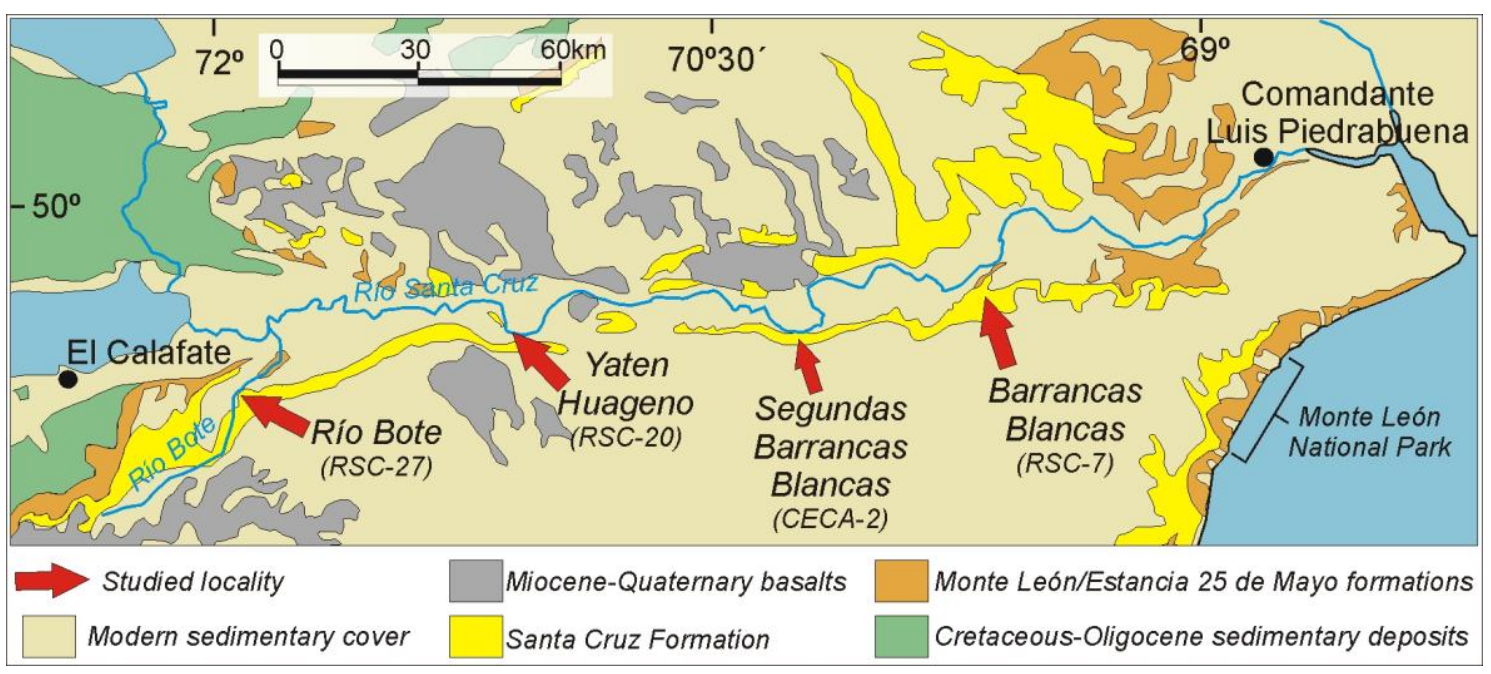



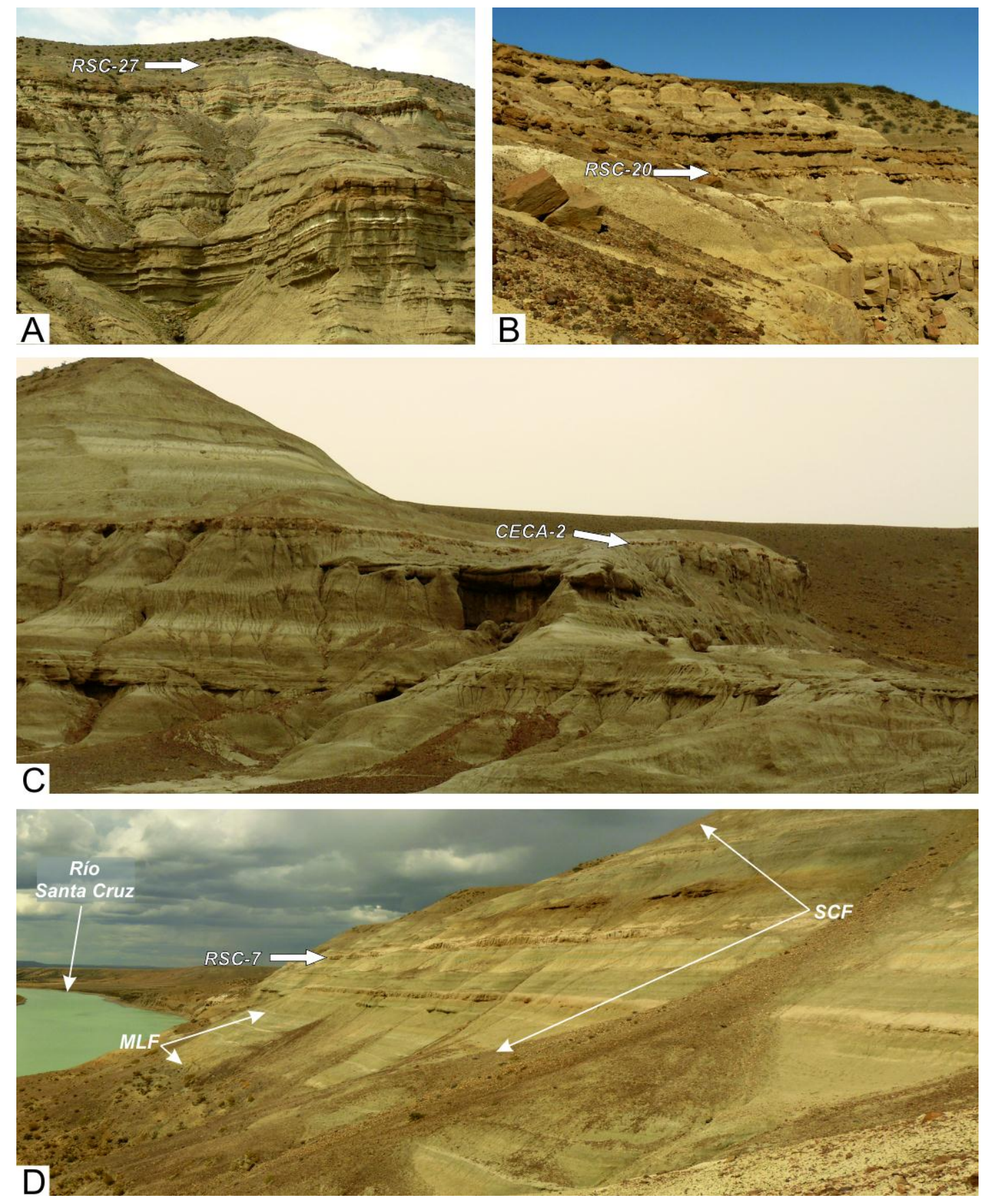
$\mathbf{W} \longleftrightarrow-215 \mathrm{~km} \longrightarrow \mathbf{E}$

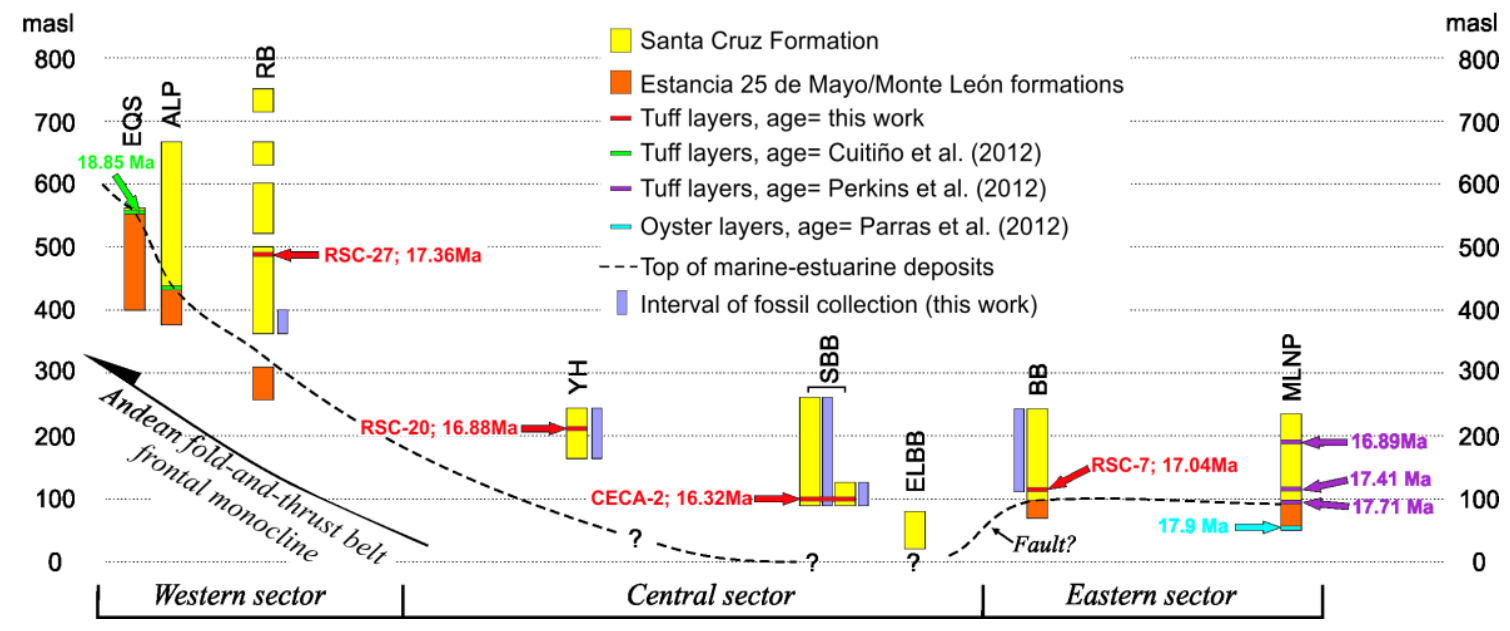



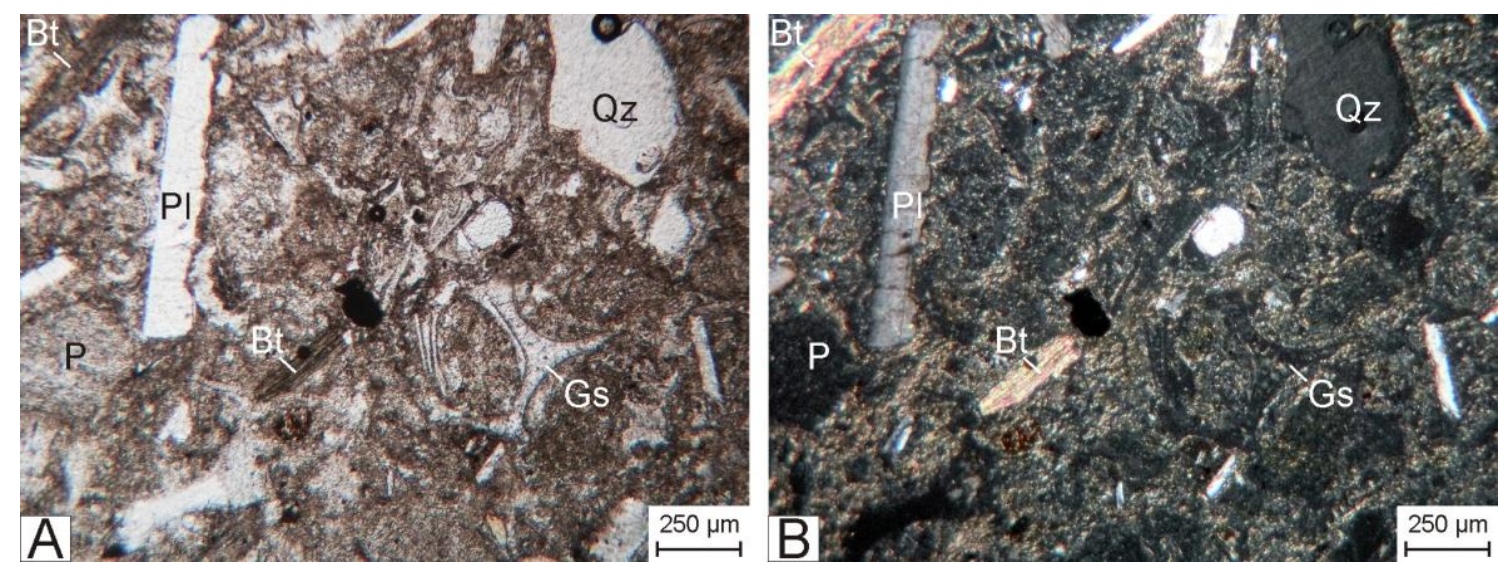


$$
8009 \text { ifll }
$$




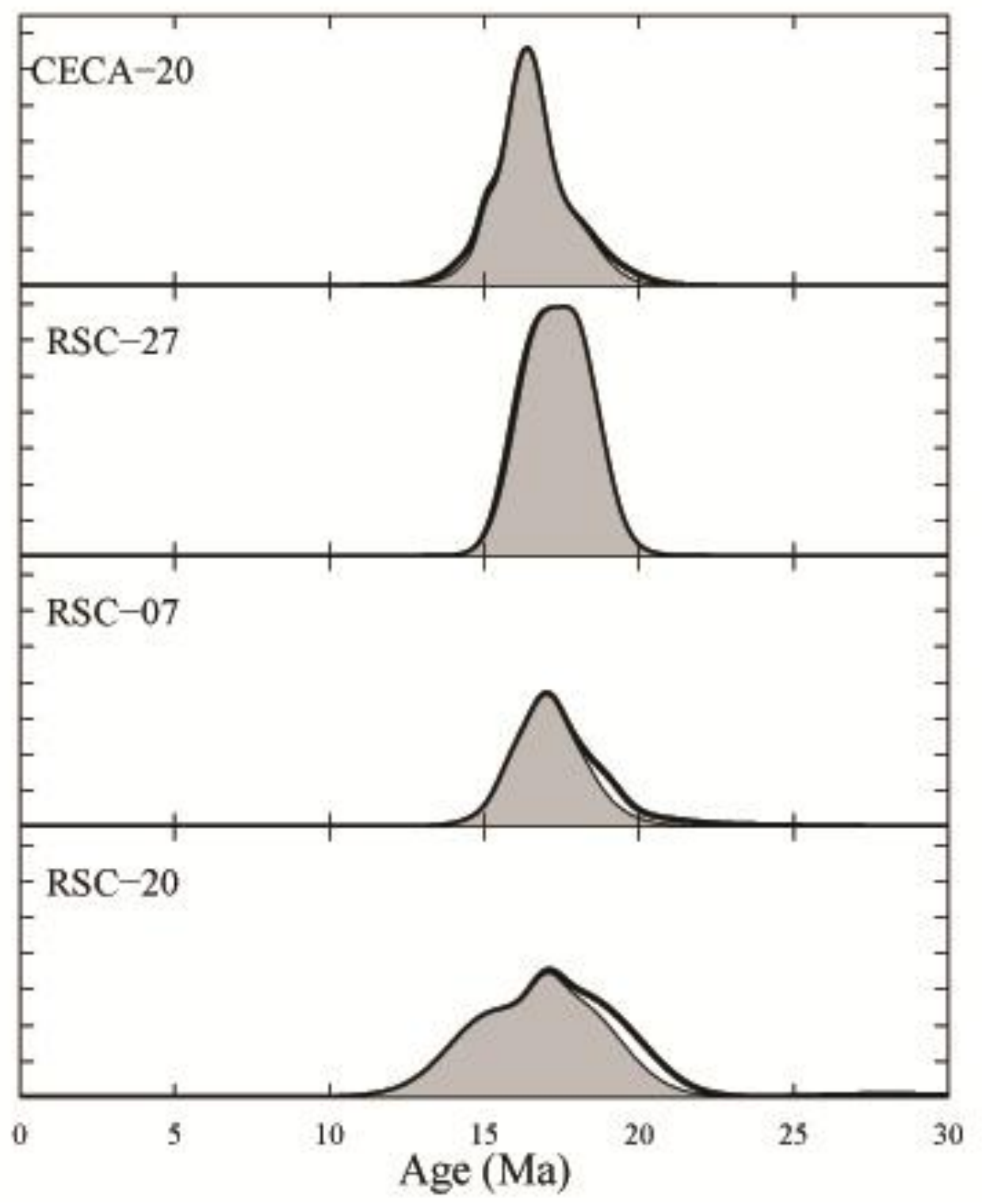




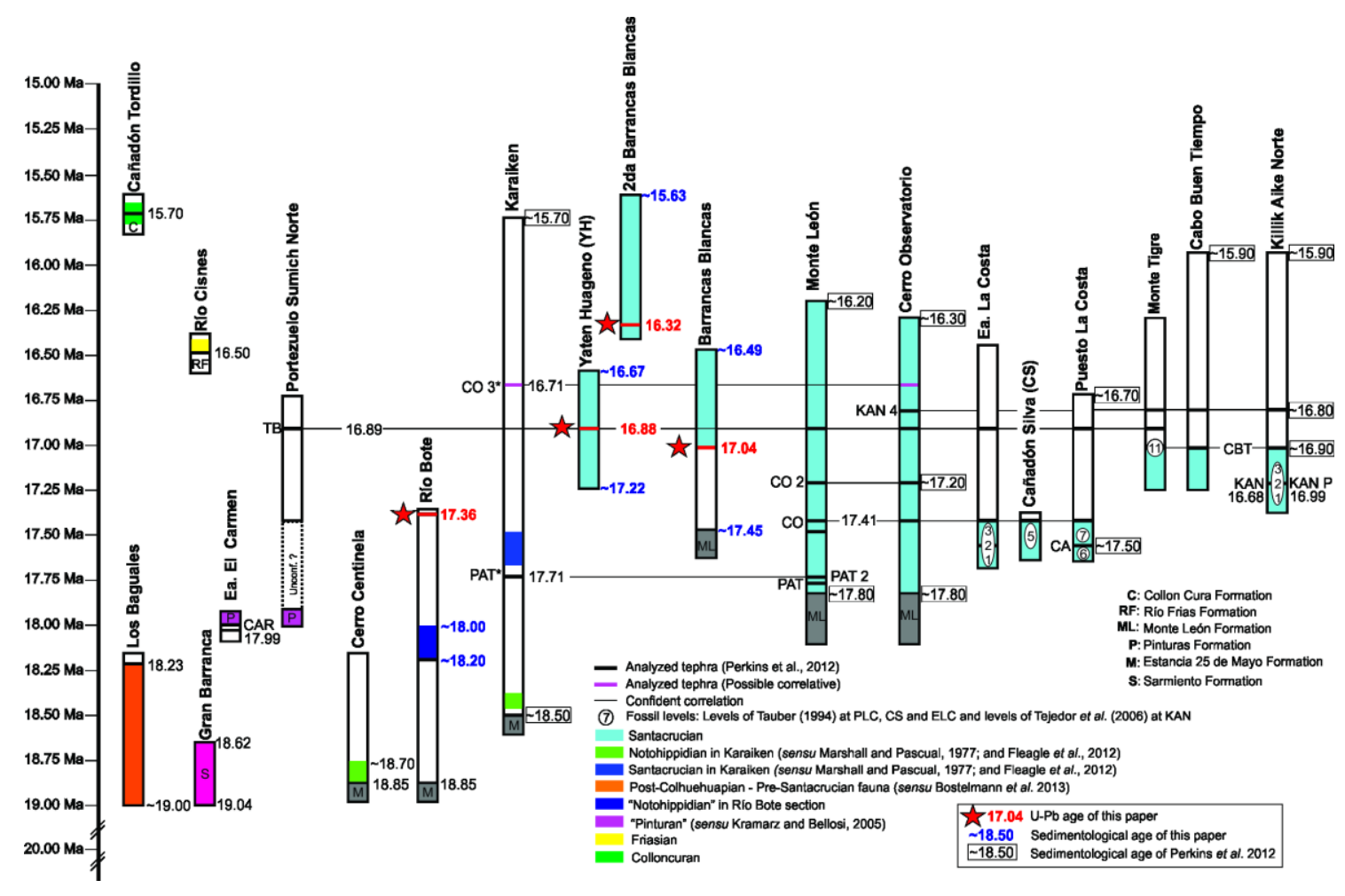




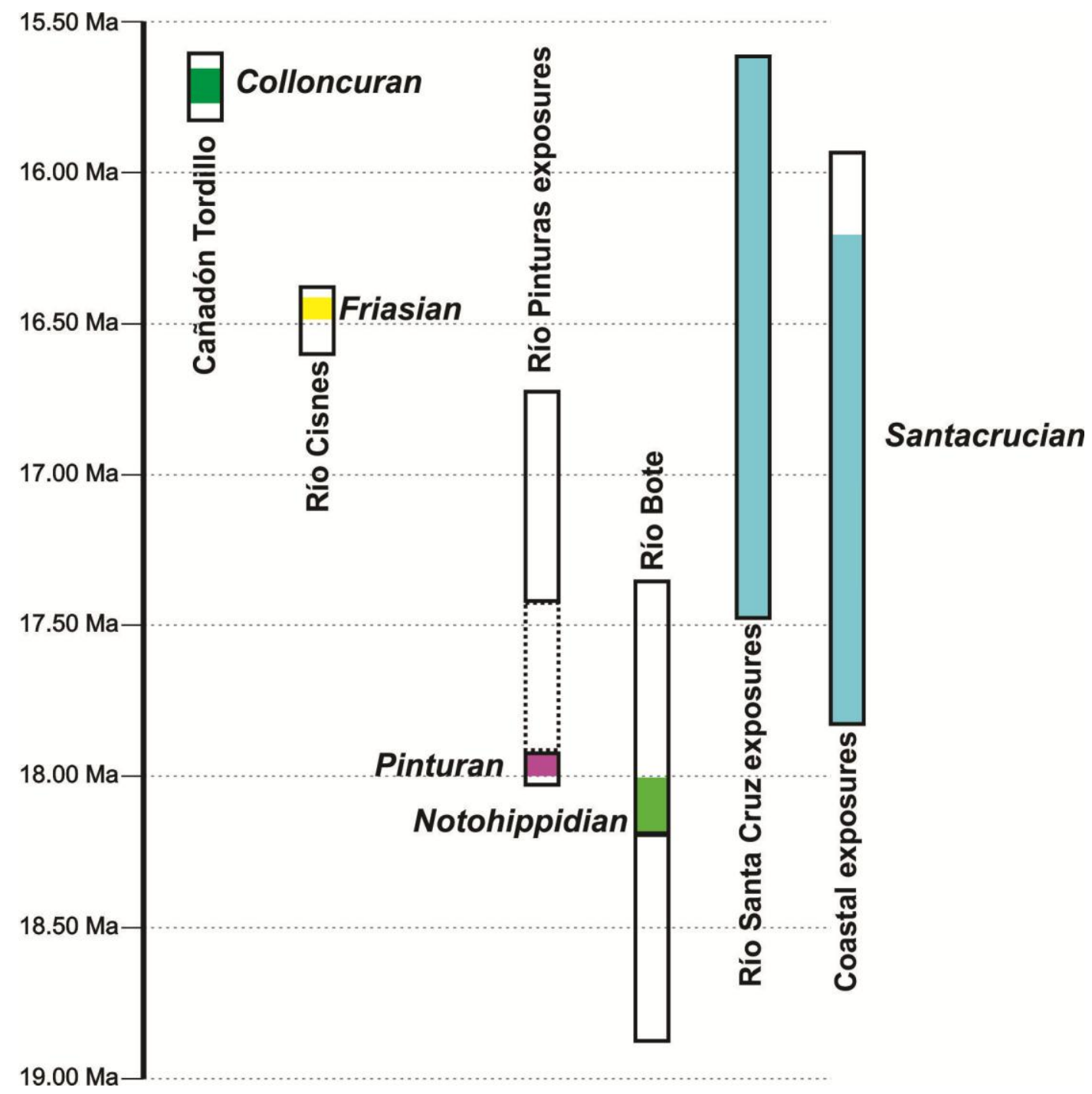




\begin{tabular}{ccccccc}
\hline \multicolumn{1}{c}{ Sample } & $\begin{array}{c}\text { Internal } \\
\text { Error }(2 \sigma) \\
(\mathrm{Ma})\end{array}$ & $\begin{array}{c}\text { Final } \\
\text { Error } \\
(\mathrm{Ma})\end{array}$ & MSWD & $\begin{array}{c}\text { Probability } \\
\text { of Fit }\end{array}$ & $\mathrm{n}$ \\
\hline CECA-20 & 16.32 & 0.32 & 0.62 & 2.6 & 0.0 & 30 \\
RSC-27 & 17.36 & 0.26 & 0.63 & 1.7 & 0.003 & 41 \\
RSC-07 & 17.04 & 0.30 & 0.55 & 1.0 & 0.48 & 20 \\
RSC-20 & 16.88 & 0.47 & 0.65 & 1.7 & 0.009 & 34 \\
\hline
\end{tabular}

